\title{
Stability Estimates for Pod Yield and Its Component Traits in Groundnut (Arachis hypogaea L.) under Farmer's Participatory Varietal Selection
}

\author{
Hasan Khan*, Vinay S. Patted, Muralidhara, B. Arunkumar and I. Shankergoud
}

AICRP on Groundnut, MARS, UAS, Raichur, Karnataka, India

*Corresponding author

\section{A B S T R A C T}

Keywords

Groundnut,

Genotype x

environment,

Stability

Article Info

Accepted:

26 December 2017

Available Online:

10 January 2018
Ten promising groundnut varieties were evaluated under farmer's participatory varietal selection method to know the genotype $\times$ environment interaction at five different locations. Analysis of variance revealed that the mean squares due to genotype were highly significant for all the characters studied. Variance due to environments was significant for all the characters studied except shelling percentage, sound mature kernels and hundred kernel weight. Significance of variance due to genotypes $\times$ environment interaction was recorded for days to maturity, plant height, shelling percentage, sound mature kernels and hundred kernel weight. A perusal of data for dry pod yield revealed that six out of the 10 genotypes, (Kadiri-9, Dharani, TG-51, TMV-2, G2-52 and GPBD-5) exhibited nonsignificant deviation from regression. Genotype Kadiri-9 recorded higher mean (1514 $\mathrm{kg} / \mathrm{ha})$ than population mean $(1405 \mathrm{~kg} / \mathrm{ha})$ with regression coefficient of 0.85 for dry pod yield, indicating this genotype performs well under different environments. Genotype Kadiri-9 found stable for major traits like dry pod yield, haulm yield and sound mature kernels indicating the potentiality of this line to exploit the hybrid vigour for pod and haulm yield.

\section{Introduction}

Groundnut (Arachis hypogaea), a segmental allopolyploid, self-pollinated legume. Popularly known as peanut or poor man's cashew. It is widely cultivated legume/oil crop in more than 114 countries including tropical to temperate region. It is an important oil, food and feed legume, where kernels are rich in oil $(48-50 \%)$ and protein $(25-28 \%)$. It stated that global groundnut production increased marginally in last decade by just $0.4 \%$ only (Jenila, et al., 2013, Nigam et al., 2014). Since Asian and African countries accounts for the
93 per cent of global groundnut production, where cultivation is predominantly under rainfed and resource poor conditions. The lower productivity in groundnut is mainly due to various biotic and abiotic stresses. Apart from these, cultivation of age old varieties which are vulnerable to majority of pests and diseases and non-availability of improved quality seeds also plays role. Many a times, improved varieties will not reach to farmers due to inefficient extension system and they may not meet the expectations of farmers, trader's, agro-based industries and other stakeholders. 
Yield is a complex character resulting from interplay of various yield contributing characters, which have positive or negative association with yield and among themselves also. The consistent performance of a genotype over a range of environments is essential for a wide stability of a variety. Stability of genotypes depends upon maintaining expression of certain morphological and physiological attributes and allowing others to vary, resulting in $\mathrm{G} \times \mathrm{E}$ interactions. $\mathrm{G} \times \mathrm{E}$ interaction has a masking effect on the performance of a genotype and hence the relative ranking of the genotype do not remain the same over number of environments. Stability of genotypes to environmental fluctuations is important for stabilization of crop production both temporally and spatially. Estimation of phenotypic stability, which involves regression analysis, has proven to be a valuable tool in the assessment of varietal adaptability. Stability analysis is useful in the identification of stable genotypes and in predicting the responses of various genotypes over changing environments. It is generally agreed that the more stable genotypes adjust their phenotypic responses to provide some measure of uniformity in spite of environmental fluctuations (Patil et al., 2014). Therefore, an attempt has been made in present study to evaluate different groundnut genotypes across the different locations to know the role of $\mathrm{G} \times \mathrm{E}$ interactions and also to analyze the stability ofgenotypes for different traits.

\section{Materials and Methods}

The experiment was conducted during kharif2015 in selected districts of HyderabadKarnataka region. Prior to this, needs of the farmers were assessed to set goals and identify farmers' preference and perception on ideotype of groundnut cultivars. Based on assessments ten high yielding groundnut genotypes (Table 1) were selected from various research institutes across India along with farmer's preferred variety (TMV-2) as check. The experiment was implemented through Mother-baby approach (Snapp, 1999) in the villages of selected districts in Hyderabad-Karnataka region where groundnut cultivation is predominant (Table 2).

Each variety was sown in an area of $1000 \mathrm{~m}^{2}$ with spacing of $30 \times 10 \mathrm{~cm}$ by following necessary agronomic practices. Each variety was grown by three different farmers in same village and observations viz., days to $50 \%$ flowering, days to maturity, plant height $(\mathrm{cm})$, number of pods/plant, shelling percent, sound mature kernals, hundred kernel weight, dry pod yield $(\mathrm{kg} / \mathrm{ha})$, kernal yield $(\mathrm{kg} / \mathrm{ha})$, haulm yield $(\mathrm{kg} / \mathrm{ha})$ was recorded in each plot and in each environment. The data were analysed for variance and pooled analysis as suggested by Panse and Sukhatme (1967). The stability analysis was carried out according to the method suggested by Eberhart and Russel (1966).

\section{Results and Discussion}

The mean squares due to genotype were highly significant for all the characters studied, which revealed the presence of substantial amount of variation among the groundnut genotypes evaluated (Table 3). Variance due to environments was significant for all the characters studied except shelling percentage; sound mature kernels and hundred kernel weight indicating that environments selected for study were highly diverse. Further, it was observed that significance as variance due to genotypes $\times$ environment interaction for days to maturity, plant height, shelling percentage, sound mature kernels and hundred kernel weight indicating that macro environmental differences were present under all three environments studied. The significant mean squares for environment (linear) for 
various traits were also reported by Habib et al., (1986) and Patil et al., (2014). Variance due to genotypes $\times$ environment (linear) was significant for days to maturity, plant height, shelling percentage and sound mature kernels. Significance of variance due to environment (linear) was observed for all the characters studied except sound mature kernels (Table 3). The higher magnitude of mean squares for environment (linear) compared to genotypes $\times$ environments (linear) indicated that linear response of environment accounted for the major part of total variation for all the characters studied and may be responsible for high adaptation in relation to yield and other traits. Therefore, prediction of performance of genotypes over environments would be possible for the various characters. Similar findings were reported by Thaw are, (2009), Pradhan et al., (2010), Habib et al., (1986) and Patil et al., (2014).Variance due to pooled deviation was significant for all the characters studied except days to $50 \%$ flowering, days to maturity, plant height and shelling percentage indicates genotypes differed considerably with respect to their stability. The significant pooled deviation (Non-linear) for various traits were also reported by Senapati et al., (2004), ChuniLal et al., (2006) and Patil et al., (2014).

Interactions of genotypes with environments obtained as the environment + genotype $\times$ environments $(e+g \times e)$ were significant for all characters except pod yield and kernel yield (Table 3), which suggested the distinct nature of environments and genotype $\times$ environment interactions in phenotypic expression. The significant environment + (genotype $\times$ environment) interactions for various traits were also reported by Joshi et al., (2003) and Patil et al., (2014).

In the present investigation, model proposed by Eberhart and Rusell (1966) was used for analysis of $\mathrm{G} \times \mathrm{E}$ interactions. This model considered both linear (bi) and non-linear $\left(S^{2} d i\right)$ components of $\mathrm{G} \times \mathrm{E}$ interactions for the prediction of performance of the individual genotype. Higher mean performance of genotype for various characters along with regression coefficient (bi) as measures of responsive and deviation from regression $\left(S^{2} d i\right)$ as a measure of stability were used to assess the stability and suitability of performance over environments. The high mean performance of genotypes was taken on the basis of average performance of all genotype as population mean.

The overall mean performance of the genotypes for days to 50 per cent flowering revealed that genotypes viz., Dharani (29), Kadiri Haritandra (28), TG-51 (28), TMV-2 (28) and GPBD-5 (28) recorded lower mean value than the population mean (29.11) with non-significant deviation from the regression (Table 4). Two genotypes, TPG-41 (1.08) and G2-52 (0.94) exhibited regression coefficient near to unity, however none of the genotypes exhibited regression coefficient near to unity (bi $\approx 1$ ) with lower mean than population mean.

The overall mean performance of the genotypes for days maturity revealed that genotypes viz., Kadiri-9 (108), Kadiri Haritandra (108), TG-37A (107), TG-51 (108) and TMV-2 (108) registered lower mean value than the population mean (109) with nonsignificant deviation from the regression (Table 4). Only one genotype TPG-41 (1.09) recorded regression coefficient near to unity, however it showed higher mean (110) than population mean (109).

The overall mean performance of the genotypes for plant height revealed that three genotypes (TPG-41, TG-51 and TMV-2) had lower mean value than the population mean with non-significant deviation from the regression. 
Table.1 List of varieties tested and their important features

\begin{tabular}{|c|c|c|c|}
\hline SI. No. & Variety Name & Developed Station & Specific features \\
\hline 1 & Kadiri-9 & ARS, Kadiri (AP) & $\begin{array}{l}\text { High yield ( } 22-25 \mathrm{q} / \mathrm{ha}) \text {, high oil content }(48- \\
50 \%) \text {, drought tolerant, moderately resistant to } \\
\text { foliar diseases }\end{array}$ \\
\hline 2 & ICGV-00351 & ICRISAT,Hyderabad & $\begin{array}{l}\text { High yield }(22-27 \mathrm{q} / \mathrm{ha}) \text {, high oil content }(48- \\
51 \%) \text {, drought tolerant, moderately resistant to } \\
\text { foliar diseases }\end{array}$ \\
\hline 3 & Dharani & RARS, Tirupati (AP) & $\begin{array}{l}\text { High yield, drought tolerant, tolerant to leaf } \\
\text { spots and suitable to rainfed areas. }\end{array}$ \\
\hline 4 & $\begin{array}{l}\text { Kadiri } \\
\text { Haritandra }\end{array}$ & ARS, Kadiri (AP) & $\begin{array}{l}\text { High yield, drought tolerant, moderately } \\
\text { resistant to foliar diseases }\end{array}$ \\
\hline 5 & TG-37A & BARC, Mumbai & $\begin{array}{l}\text { High yield }(22-25 \mathrm{q} / \mathrm{ha}) \text {, bold seeded, smooth } \\
\text { pods, high harvest index }\end{array}$ \\
\hline 6 & TPG-41 & BARC, Mumbai & Table purpose, large seeded, $\mathrm{O} / \mathrm{L}$ ratio 3.2 \\
\hline 7 & TG-51 & BARC, Mumbai & High yield ( $25-27$ q/ha), oil content (49 \%) \\
\hline 8 & $\mathrm{G}_{2}-52$ & $\begin{array}{l}\text { UAS, Dharwad } \\
\text { (Kar) }\end{array}$ & $\begin{array}{l}\text { Resistant to late leaf spot and rust diseases, } \\
\text { high yield ( } 25-30 \mathrm{q} / \mathrm{ha} \text { ), good kernel feature as } \\
\text { TMV-2 }\end{array}$ \\
\hline 9 & GPBD-5 & $\begin{array}{l}\text { UAS, Dharwad } \\
\text { (Kar) }\end{array}$ & $\begin{array}{l}\text { Resistant to leaf spots, high yielder ( } 25-30 \\
\text { q/ha), bold seeded. }\end{array}$ \\
\hline 10 & $\begin{array}{l}\text { TMV } \\
\text { (farmer's } \\
\text { preferred } \\
\text { variety) }\end{array}$ & TNAU,Coimbatore & $\begin{array}{l}\text { Widely adoptable, susceptible to pest and } \\
\text { diseases and low yielder. }\end{array}$ \\
\hline
\end{tabular}

Table.2 List of FPVS trials conducted during Kharif-2015

\begin{tabular}{|l|l|c|c|c|}
\hline $\begin{array}{l}\text { Name of } \\
\text { District }\end{array}$ & Name of Location & $\begin{array}{c}\text { Mother } \\
\text { trail }\end{array}$ & $\begin{array}{c}\text { Baby } \\
\text { trails }\end{array}$ & $\begin{array}{c}\text { Total number of } \\
\text { trials }\end{array}$ \\
\hline Raichur & $\begin{array}{l}\text { Devadurga: Sasvigera } \\
\text { Lingasuguru: Golapalli }\end{array}$ & 1 & 10 & 11 \\
\hline Yadgir & Surapura : Shrinivaspura & 1 & 10 & 11 \\
\hline Bellary & $\begin{array}{l}\text { Huvinahadagali: } \\
\text { Chikkakolachi }\end{array}$ & 1 & 10 & 11 \\
\hline Koppal & Koppal : Thighari & 1 & 10 & 11 \\
\hline Total & & $\mathbf{5}$ & $\mathbf{5 0}$ & $\mathbf{5 5}$ \\
\hline
\end{tabular}

Where, Mother trails = evaluation of all genotypes, Baby trial = evaluation of only two genotypes (paired comparison) 
Table.3 ANOVA for $\mathrm{G} \times \mathrm{E}$ interaction of 10 quantitative traits over five environments

\begin{tabular}{|c|c|c|c|c|c|c|c|c|c|c|c|}
\hline $\begin{array}{l}\text { Source of } \\
\text { variation }\end{array}$ & Df & $\begin{array}{c}\text { Days to } \\
50 \% \\
\text { flowering }\end{array}$ & $\begin{array}{l}\text { Days to } \\
\text { maturity }\end{array}$ & $\begin{array}{c}\text { Plant } \\
\text { height } \\
(\mathrm{cm})\end{array}$ & $\begin{array}{c}\text { Number } \\
\text { of } \\
\text { pods/plant }\end{array}$ & $\begin{array}{l}\text { Shelling } \\
\text { percent }\end{array}$ & $\begin{array}{l}\text { Sound } \\
\text { mature } \\
\text { kernals }\end{array}$ & $\begin{array}{l}\text { Hundred } \\
\text { kernel } \\
\text { weight } \\
\text { (g) }\end{array}$ & $\begin{array}{c}\text { Dry pod } \\
\text { yield(kg/ha) }\end{array}$ & $\begin{array}{c}\text { kernal } \\
\text { yield(kg/ha) }\end{array}$ & $\begin{array}{c}\text { haulm yield } \\
\text { (kg/ha) }\end{array}$ \\
\hline Genotypes & 9 & $5.75^{* * *}$ & $13.79 * * *$ & $27.35 * * *$ & $20.28 * *$ & $25.19 * * *$ & $30.37 * *$ & $23.07 * * *$ & $53687.8 * * *$ & 43487.6 *** & $335707.3^{* * *}$ \\
\hline $\begin{array}{l}\text { Env. + }(G \times \\
\text { E) }\end{array}$ & 40 & $0.63 *$ & $2.08 * *$ & $6.24 *$ & $8.33 *$ & $5.94 * *$ & $8.13 * *$ & $2.90 * *$ & 14169.26 & 9146.46 & $88517.38 * *$ \\
\hline Environments & 4 & $2.34 * * *$ & $7.34 * * *$ & $29.64 * * *$ & $34.32 * * *$ & 3.85 & 4.18 & 5.79 & $36779.08 *$ & $23422.56^{*}$ & $229663.3^{*}$ \\
\hline $\mathbf{G} \times \mathbf{E}$ & 36 & 0.44 & $1.49 *$ & $3.64 *$ & 5.45 & $6.17 * *$ & $8.57 *$ & $2.58 *$ & 11657.06 & 7560.23 & 72384.5 \\
\hline $\begin{array}{l}\text { Environments } \\
\text { (Lin.) }\end{array}$ & 1 & $9.37 * * *$ & $29.37 * * *$ & $118.57 * * *$ & $137.3 * * *$ & $15.42 *$ & 16.75 & $23.17 * *$ & $147116.2 * * *$ & $93690.2 * * *$ & $918653.3 * * *$ \\
\hline $\mathbf{G} \times \mathbf{E}($ Lin. $)$ & 9 & 0.80 & $3.25 * *$ & $4.82 *$ & 7.26 & $17.26 * * *$ & $5.32 *$ & 2.03 & 12747.2 & 7924.9 & 79607.5 \\
\hline $\begin{array}{l}\text { Pooled } \\
\text { Deviation }\end{array}$ & 30 & 0.23 & 0.81 & $2.92 * *$ & $4.36 * * *$ & 2.22 & $8.69 * *$ & 2.03 & $10164.3^{* * *}$ & $6694.80 * * *$ & $63519.1 * * *$ \\
\hline Pooled error & 45 & 1.09 & 1.26 & 1.09 & 0.99 & 5.94 & 3.28 & 4.70 & 995.90 & 1585.17 & 6225.6 \\
\hline Total & 49 & 1.57 & 4.23 & 10.11 & 10.53 & 9.47 & 6.60 & 12.21 & 21427.8 & 15454.01 & 133919.6 \\
\hline
\end{tabular}

$* *=>$ Significant at $\mathrm{P}=0.01, *=>$ Significant at $\mathrm{P}=0.05$ 
Table.4 Stability parameters for seed yield and its attributing traits in groundnut

\begin{tabular}{|c|c|c|c|c|c|c|c|c|c|c|c|c|c|c|c|c|c|c|c|}
\hline \multirow[t]{2}{*}{$\begin{array}{l}\text { Sl. } \\
\text { no. }\end{array}$} & \multirow[t]{2}{*}{ Genotype } & \multicolumn{3}{|c|}{$\begin{array}{l}\text { Days to } 50 \% \\
\text { flowering }\end{array}$} & \multicolumn{3}{|c|}{ Days to Maturity } & \multicolumn{3}{|c|}{ Plant Height (cm) } & \multicolumn{3}{|c|}{$\begin{array}{l}\text { Number of } \\
\text { pods/plant }\end{array}$} & \multicolumn{3}{|c|}{ Shelling percentage } & \multicolumn{3}{|c|}{$\begin{array}{c}\text { Hundred kernel } \\
\text { Weight }\end{array}$} \\
\hline & & X & $S^{2}$ di & bi & $\mathbf{X}$ & $S^{2}$ di & bi & $\mathbf{X}$ & $S^{2} \mathbf{d i}$ & bi & $\mathbf{X}$ & $S^{2}$ di & bi & $\mathbf{X}$ & $\mathbf{S}^{2} \mathbf{d i}$ & bi & $\mathbf{X}$ & $S^{2}$ di & bi \\
\hline 1 & Kadiri-9 & 31 & 0.43 & 3.39 & 108 & -1.42 & -0.2 & 40.5 & $3.64 * *$ & 1.81 & 28 & $5.08 * *$ & 1.03 & 72.2 & -2.05 & 10.35 & 38.5 & -6.13 & -0.38 \\
\hline 2 & $\begin{array}{l}\text { ICGV- } \\
00351\end{array}$ & 30 & -1.16 & 0.16 & 112 & -1.63 & 0.68 & 38.1 & -0.58 & 0.86 & 26 & $12.33 * *$ & 1.47 & 70.9 & -6.19 & -0.12 & 38.4 & $11.08 *$ & -0.63 \\
\hline 3 & Dharani & 29 & -1.16 & 0.49 & 110 & -1.66 & 2.85 & 36.5 & $5.09 * *$ & 1.3 & 26 & 0.01 & 1.2 & 72.6 & -5.35 & 0.04 & 38.8 & -5.71 & 0.61 \\
\hline 4 & K Haritendra & 28 & -1.17 & 0.54 & 107 & -1.21 & 0.17 & 39.8 & $2 *$ & 0.86 & 25 & 1.99 & 0.38 & 70.6 & -6.02 & 0.05 & 36.1 & -5.91 & 1.52 \\
\hline 5 & TG-37A & 30 & -1.22 & 0.88 & 107 & -1.11 & 0.3 & 38.4 & $2.43 *$ & 0.17 & 25 & $4.37 * *$ & 0.31 & 69.6 & -5.98 & -0.34 & 36.6 & -6.1 & 1.53 \\
\hline 6 & TPG-41 & 30 & -1.25 & 1.08 & 110 & -2.38 & 1.09 & 34.8 & 1.73 & 0.46 & 23 & $3.38 * *$ & 0.15 & 71.5 & -5.34 & 0.71 & 37.1 & -5.38 & 1.77 \\
\hline 7 & TG-51 & 28 & -1.24 & 0.3 & 107 & -2.03 & 0.1 & 33 & 0.78 & 0.47 & 23 & $3.82 * *$ & 0.25 & 66.5 & -5.82 & -0.36 & 38.1 & -5.53 & 1.83 \\
\hline 8 & TMV-2 & 28 & -1.22 & 0.74 & 108 & -1.63 & 2.47 & 37.3 & 1.09 & 2.05 & 22 & -0.25 & 1.17 & 66.6 & -1.99 & 1.25 & 32 & -2.81 & 2.11 \\
\hline 9 & G2-52 & 29 & -1.16 & 0.94 & 111 & -1.43 & 1.86 & 38.7 & 1.62 & 1.5 & 25 & 1.28 & 2.38 & 67.4 & 4.19 & -0.75 & 35.9 & -4.78 & 0.66 \\
\hline 10 & GPBD-5 & 28 & -1.06 & 1.48 & 108 & -1.82 & 0.69 & 39.5 & 1.1 & 0.51 & 28 & $2.03 *$ & 1.66 & 70.1 & -5.71 & -0.84 & 39.4 & -5.68 & 0.97 \\
\hline & Mean & 29.11 & & & 109 & & & 37.66 & & & 25 & & & 70 & & & 37 & & \\
\hline
\end{tabular}

Table.4 Contd...

\begin{tabular}{|c|c|c|c|c|c|c|c|c|c|c|c|c|c|}
\hline \multirow{2}{*}{$\begin{array}{l}\text { Sl. } \\
\text { no. }\end{array}$} & \multirow[t]{2}{*}{ Genotype } & \multicolumn{3}{|c|}{ Sound mature kernals (\%) } & \multicolumn{3}{|c|}{ Dry Pod Yield (kg/ha) } & \multicolumn{3}{|c|}{ Kernel Yield (Kg/ha) } & \multicolumn{3}{|c|}{ Haulm Yield (Kg/ha) } \\
\hline & & $\mathbf{X}$ & $S^{2} d i$ & bi & $\mathbf{X}$ & $S^{2}$ di & bi & $\mathbf{X}$ & $S^{2}$ di & bi & $\mathbf{X}$ & $\mathbf{S}^{2} \mathrm{di}$ & bi \\
\hline 1 & Kadiri-9 & 72.6 & -1.77 & 0.67 & 1514 & 879 & 0.85 & 1094 & $5248^{*}$ & 2.2 & 3785 & 5419 & 0.85 \\
\hline 2 & ICGV-00351 & 69 & -0.67 & -0.67 & 1508 & $26045 * *$ & 0.53 & 1070 & $12705^{* *}$ & 0.18 & 3772 & $162659 * *$ & 0.53 \\
\hline 3 & Dharani & 69.6 & -1.03 & -0.15 & 1379 & 391 & 1.85 & 1001 & -1154 & 1.6 & 3447 & 2463 & 1.85 \\
\hline 4 & K. Haritendra & 67.6 & 11.67 & 2.37 & 1358 & $2775^{*}$ & 0.05 & 959 & -3.59 & 0.19 & 3396 & 17288 & 0.05 \\
\hline 5 & TG-37A & 65.4 & 21.44 & 2.27 & 1367 & $16928 * *$ & 0.7 & 957 & $5357 *$ & 0.75 & 3417 & $105648 * *$ & 0.7 \\
\hline 6 & TPG-41 & 69.4 & 6.55 & -2.36 & 1390 & $14258 * *$ & -0.12 & 994 & $8014 * *$ & 0.02 & 3474 & $89382 * *$ & -0.12 \\
\hline 7 & TG-51 & 69.5 & -2.12 & 2.27 & 1279 & 9076 & 0.35 & 850 & 2758 & 0.29 & 3197 & $56697 * *$ & 0.35 \\
\hline 8 & TMV-2 & 66.2 & 11.85 & 2.73 & 1282 & -529 & 1.19 & 853 & 1384 & 0.87 & 3205 & -3285 & 1.19 \\
\hline 9 & $\mathrm{G} 2-52$ & 71.8 & 9.98 & 2.96 & 1372 & 1109 & 2.9 & 927 & 3864 & 2.71 & 3429 & 7112 & 2.9 \\
\hline 10 & GPBD-5 & 72.4 & -3.19 & -0.09 & 1598 & 1171 & 1.71 & 1121 & $14609 * *$ & 1.18 & 3996 & $132150 * *$ & 1.71 \\
\hline & Mean & 69.4 & & & 1405 & & & 983 & & & 3512 & & \\
\hline
\end{tabular}

Where, $\mathrm{X}=$ Environment mean, $\mathrm{S}^{2} \mathrm{di}=$ Deviation from regression, bi = Regression co-efficient 
The genotype ICGV-00351recorded higher mean (38.10) than population mean (37.66). None of the varieties evaluated recorded regression coefficient near to unity. These results were in accordance with the Senapati et al., (2004), Chuni Lal et al., (2006), Hariprasana et al., (2008) and Pradhan et al., (2010).

Genotype Dharani registered higher mean value of 26than the population mean (25) for number of pods per plant with non-significant deviation from the regression (Table 4) and genotype Kadiri-9 (1.03) recorded regression coefficient near to unity.

The overall mean performance of the genotypes for shelling percentage revealed that genotypes viz., Kadiri-9 (72.2), ICGV00351 (70.9), Dharani (72.6), Kadiri Haritandra (70.6), TPG-41 (71.5) and GPBD5 (70.1)recorded higher mean value than the population mean (70.1) with non-significant deviation from the regression. None of the varieties evaluated recorded regression coefficient near to unity with higher mean than population mean (Table 4).

The overall mean performance of the genotypes for hundred kernel weight revealed that that five genotypes Kadiri-9 (38.5), ICGV00351 (38.4), Dharani (38.8), TG-51 (38.1) and GPBD-5 (39.4) had higher mean value than the population mean (37) with nonsignificant deviation from the regression. Out of five the genotype GPBD-5 exhibited regression coefficient nearly unity $(0.97)$ with higher mean than population mean indicating genotype performs well under different environmental conditions. For sound mature kernals, the overall mean performance of the genotypes revealed that three genotypes Kadiri-9 (72.6), G2-52 (71.8) and GPBD-5 (72.4) had higher mean value than the population mean with non-significant deviation from the regression. Out of three the genotype G2-52 exhibited regression coefficient more than unity (2.96) with higher mean than population mean indicating this genotype is specifically adapted to favorable environment. These results were in accordance with the Habib et al., (1986), Chuni Lal et al., (2006), Hariprasana et al., (2008) and Pradhan et al., (2010) Patil et al., (2014).

A perusal of data for dry pod yield revealed that out of the 10 genotypes, six genotypes viz., Kadiri-9, Dharani, TG-51, TMV-2, G252 and GPBD-5 exhibited non-significant deviation from regression indicating their predictable behavior (Table 4). The six genotypes viz. Kadiri-9 (0.85), ICGV00351 (0.53), Kadiri Haritandra (0.05), TG-37A (0.7), TPG-41 (-0.12) and TG-51 (0.35) expressed regression coefficient less than unity (bi<1), while four genotypes Dharani (1.85), TMV-2 (1.19), G2-52 (2.9) and GPBD-5 (1.71) exhibited regression coefficient greater than unity (bi>1). Genotypes with regression coefficient less than unity (bi<1) and more than unity (bi $>1)$ are expected to show stability for dry pod yield in unfavorable and favorable environments, respectively.

Genotype Kadiri-9 exhibited higher mean (1514 kg/ha) than population mean (1405 $\mathrm{kg} / \mathrm{ha}$ ) but recorded regression coefficient less than unity (0.85) indicating its good performance under different environments. The genotype GPBD-5 exhibited regression coefficient more than unity (1.71) with higher mean $(1598 \mathrm{~kg} / \mathrm{ha})$ than population mean (1405 kg/ha) indicating this genotype is specifically adapted to favorable environment. These results were in accordance with the Habib et al., (1986), Senapati et al., (2004), Chuni Lal et al., (2006), Hariprasana et al., (2008), Pradhan et al., (2010) and Patil et al., (2014).Genotypes viz. Dharani, Kadiri Haritandra, TG-51,TMV-2 and G2-52 
exhibited non-significant deviation from regression indicating their predictable behavior (Table 4).

Genotypes viz. ICGV00351 (0.18), Kadiri Haritandra (0.19), TG-37A (0.75), TPG-41 (0.02), TG-51 (0.29) and TMV-2 (0.87) expressing regression coefficient less than unity $($ bi<1) are expected to show stability for kernel yield in unfavorable environments. Four genotypes Kadiri-9 (2.2), Dharani (1.6), G2-52 (2.71) and GPBD-5 (1.18) exhibited regression greater than unity $(\mathrm{bi}>1)$ and are expected to show stability for kernel yield favorable environments, respectively. None of the genotypes exhibited regression coefficient nearly equal to unity (bi $\approx 1$ ) with higher mean than population mean. The genotype TMV-2 exhibited regression coefficient nearly equal to unity $(0.87)$ with lower mean $(853 \mathrm{~kg} / \mathrm{ha})$ than population mean $(983 \mathrm{~kg} / \mathrm{ha})$ indicating this genotype is poorly adapted to all environments. These results were in accordance with the Habib et al., (1986), Senapati et al., (2004), Chuni Lal et al., (2006), Hariprasana et al., (2008), Pradhan et al., (2010) and Patil et al., (2014).

Breeding genotypes with only high yield potential will not achieve the desirable results because the per se performance may not be evident in all situations. Therefore, it is imperative that along with per se performance due weightage should be given to the yield stability also (Ceccarelli, 1989). Stability for yield is likely to be dependent upon stability of its yield attributing characters. Hence stability of yield components may ultimately result in the emergence of a stable genotype with high yield potential under varying environments. In the present study genotype Kadiri-9 found stable for major traits like dry pod yield, haulm yield and Sound mature kernels indicating the potentiality of this line to exploit as a parents in hybridization programme for pod and haulm yield.

\section{References}

Allard, R. W., 1961. Relationship between genetic diversity and consistency of performance in different environments. Crop Science, 1: 127-133.

Ceccarelli, S., 1989, Wide adaptation: How wide? Euphytica, 40: 197-205.

ChuniLal, R., Rathnakumar, A.L., Hariprasanna, K., Gor, H. K. and Chikani, B.M., 2006. Early maturing groundnut advanced breeding lines with high day-1 productivity under rainfed situations. e-journal. icrisat.org, 5(1): 4.

Eberhart, S. A. and Russel, W. A., 1966. Stability parameters for comparing varieties. Crop Science, 6: 36-40.

Habib, A.F., Nadaf, H.L., Kulkarni, G. K. and Nadiger, S.D., 1986. Stability analysis of pod yield in bunch groundnut. Journal of Oilseeds Research, 3: 46-50.

Hariprasanna, K., ChuniLal and Radhakrishnan, T., 2008. Genotype $\times$ environmental interactions and stability analysis in large seeded genotypes of groundnut (Arachis hypogaea L). Journal of Oilseeds Research, 25(2): 126-131.

Janila, P., Nigam, S. M., Pandey, M., Nagesh, P. and Varshney, R. K., 2013. Groundnut improvement: use of genetic and genomic tools. Frontiers in plant science, 4:23.

Joshi, H.J., Vekaria, G. B. and Mehta, D. R., 2003. Stability analysis for morphophysiological traits in groundnut. Legume Research, 26(1): 20-23.

Panse, V. G. and Sukhatme, P. V., 1967. Statistical methods for agricultural workers, ICAR Publication, New Delhi. pp. 359.

Patil, A. S., Nandawar, H. R., Punewar, A. A. and Shah, K. P., 2014. Stability for yield and its component traits in groundnut (Arachis hypogaea L.). International Journal of Bio-resource 
and Stress Management, 5(2):240-245.

Pradhan, K., Das, P. K. and Patra, R. K., 2010. Genotype $\times$ environment interaction for pod yield and components of groundnut varieties in warm sub-humid climate and moderately acidic soil. Indian Journal of Genetics, 70(2): 201- 203.

Senapati, B. K., Maity, D. and Sarkar, G., 2004. Stability evaluation of summer groundnut (Arachis hypogaea L.) under coastal saline zone of West Bengal. Legume Research, 27(2): 103-106.

Snapp, S.1999. Mother and baby trials: a novel trial design being tried out in Malawi. Target-Newsletter of the South African Soil Fertility Network, 17: 810.

Thaware, B. L., 2009. Stability analysis for dry pod yield in Spanish bunch groundnut. Agricultural Science Digest, 29(3): 221-223.

\section{How to cite this article:}

Hasan Khan, Vinay S. Patted, Muralidhara, B. Arunkumar and Shankergoud, I. 2018. Stability Estimates for Pod Yield and Its Component Traits in Groundnut (Arachis hypogaea L.) under Farmer's Participatory Varietal Selection. Int.J.Curr.Microbiol.App.Sci. 7(01): 3171-3179. doi: https://doi.org/10.20546/ijcmas.2018.701.378 